\title{
Knowledge and practices related to menstruation among rural college going girls in Varanasi district
}

\author{
SADHANA SINGH RAJPOOT AND KALPNA GUPTA
}

Received: 15.04.2015; Revised: 20.04.2015; Accepted: 01.05.2015

See end of the paper for authors' affiliations SADHANA SINGH RAJPOOT Department of Home Science, Mahila Mahavidyalaya, Banaras Hindu University, VARANASI (U.P.) INDIA

Email : sadhana86.singh@gmal.com
ABSTRACT : The main objective of this study is to assess knowledge, practices, and perception of rural college going girls, during their menstruation. The study was carried out from August, 2013 to November, 2013 in Varanasi, India. Data was collected by using pre-structured and pre tested questionnaire. Total 360 college going girls were included in the study who were studying in graduation courses. Girls were between the age group of 17 to 23 year with mean age 18.89 year. Result shows that only 29.2 per cent girls having prior knowledge about menstrual cycle before their menarche while rest 70.8 did not know about the same, among 44.8 per cent respondent source of information were mothers. Majority $(76.1 \%)$ of participants were suffering from pain during menstruation. Except 1.7 per cent girls rest were following some kind of restrictions during these days. This paper reemphasizes the important, urgent and neglected need of providing correct knowledge to the community including adolescent girls.

KEY WORDS: Knowledge, Menarche, College going girls, Restriction

- HOW TO CITE THIS PAPER : Rajpoot, Sadhana Singh and Gupta, Kalpna (2015). Knowledge and practices related to menstruation among rural college going girls in Varanasi district. Asian J. Home Sci., 10 (1) : 168-173. 